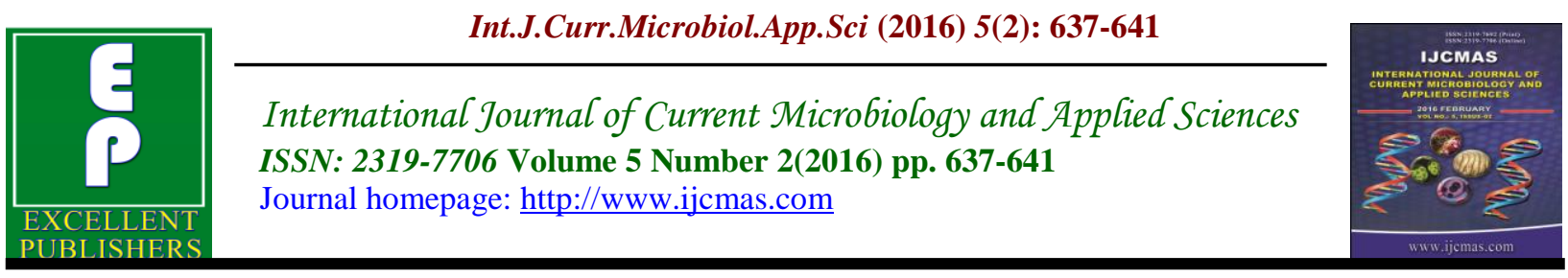

Original Research Article

doi: http://dx.doi.org/10.20546/ijcmas.2016.502.071

\title{
Microbial Diversity of Soil in Some Coal Mine Generated Wasteland of Raniganj Coalfield, West Bengal, India
}

\author{
Payel Majumder ${ }^{1 *}$ and Debnath Palit $^{2}$ \\ ${ }^{1}$ Department of Conservation Biology, The University of Burdwan, India \\ ${ }^{2}$ Department of Botany, Dugrapur Government College, The University of Burdwan, India \\ *Corresponding author
}

\begin{tabular}{|c|c|}
\hline & $\begin{array}{l}\text { A B S T R A C T } \\
\text { The present study was conducted to determine the microbial diversity of soil in } \\
\text { some coal mine generated wasteland of Raniganj Coalfield area. Seven different } \\
\text { soil samples were collected from seven different sites namely Nagrakunda, Topsi } \\
\text { colliery, Sidhuli, Sankerpur kenda, Bankola, Parascul, Sonepur Bazari of Raniganj } \\
\text { Coalfield. Topography, vegetation, mining type, mining area, status of mining } \\
\text { operation, biological reclamation activity was considered as basis of the sample } \\
\text { selection. Soil physicochemical characteristics were also analyzed. For } \\
\text { microbiological study, soil samples were processed according to standard } \\
\text { microbiological techniques. The results of the present study enlighted that in our } \\
\text { study area heterotrophic, gram negative, phosphate solubilizing bacterial } \\
\text { population was quite high in Sankerpur kenda area whereas gram positive bacterial } \\
\text { population was low in this area. Nagrakunda showed much higher gram negative } \\
\text { bacterial population whereas Bankola showed lower gram negative, nitrate } \\
\text { reducing and phosphate solubilizing bacterial population with low organic carbon, } \\
\text { potassium content. Gram positive bacterial population was high in Topsi colliery } \\
\text { and Sidhuli showed high nitrate reducing bacterial population. Overall, different } \\
\text { area of Raniganj coalfield showed different picture of bacterial population with low } \\
\text { nitrogen (except Bankola), potassium (except Nagrakunda), organic carbon (except } \\
\text { Sonepur Bazari) and medium phosphorus content (except Sidhuli). }\end{array}$ \\
\hline & \multirow{13}{*}{$\begin{array}{l}\text { The present study was conducted to determine the microbial diversity of soil in } \\
\text { some coal mine generated wasteland of Raniganj Coalfield area. Seven different } \\
\text { soil samples were collected from seven different sites namely Nagrakunda, Topsi } \\
\text { colliery, Sidhuli, Sankerpur kenda, Bankola, Parascul, Sonepur Bazari of Raniganj } \\
\text { Coalfield. Topography, vegetation, mining type, mining area, status of mining } \\
\text { operation, biological reclamation activity was considered as basis of the sample } \\
\text { selection. Soil physicochemical characteristics were also analyzed. For } \\
\text { microbiological study, soil samples were processed according to standard } \\
\text { microbiological techniques. The results of the present study enlighted that in our } \\
\text { study area heterotrophic, gram negative, phosphate solubilizing bacterial } \\
\text { population was quite high in Sankerpur kenda area whereas gram positive bacterial } \\
\text { population was low in this area. Nagrakunda showed much higher gram negative } \\
\text { bacterial population whereas Bankola showed lower gram negative, nitrate } \\
\text { reducing and phosphate solubilizing bacterial population with low organic carbon, } \\
\text { potassium content. Gram positive bacterial population was high in Topsi colliery } \\
\text { and Sidhuli showed high nitrate reducing bacterial population. Overall, different } \\
\text { area of Raniganj coalfield showed different picture of bacterial population with low } \\
\text { nitrogen (except Bankola), potassium (except Nagrakunda), organic carbon (except } \\
\text { Sonepur Bazari) and medium phosphorus content (except Sidhuli). }\end{array}$} \\
\hline Keywords & \\
\hline & \\
\hline Diversity of Soil, & \\
\hline & \\
\hline & \\
\hline \multirow{2}{*}{ Article Info } & \\
\hline & \\
\hline & \\
\hline & \\
\hline & \\
\hline & \\
\hline & \\
\hline
\end{tabular}

\section{Introduction}

Each soil habitat has unique and well adapted microbial guilds whose functionalities maintain its nutritional status, degrade pollutants and control different pests and diseases. Soil consists of layers of mineral of variable thicknesses having a difference from the parent materials in their morphological, physical, chemical, and mineralogical characteristics. Productivity and sustainability of soil's health is directly influenced by qualitative and quantitative activities of microorganisms (Atlas et al, 1991, Kaneko et al, 1977). Soil contains carbon in the deep oceans (Raich and Potter, 1995 and Schimel, 1995), largest stores of nitrogen in terrestrial ecosystems (Schlesinger, 1997). With increasing rates of anthropogenic $\mathrm{N}$ deposition ( Vitousek et al., 1997), there is a strong need to understand links between $\mathrm{N}$ inputs and soil respiration. 
Nevertheless, most of the data available so far are limited to qualitative descriptions of bacterial distributions. In soil, a significant proportion of the microbes serve as pathogen/competitor/symbiotic agent, predator/ antagonist of other microbes/organisms (Chatterjee et al., 2008; Das et al, 2008, Chatterjee and Ghosh, 2010; Chatterjee et al, 2010, Chatterjee et al ,2011, Chatterjee et al,2012). Coal is a valuable resource. It provides a significant amount of the world's energy supply and it is the basis for many industries. Coal mining becomes a major industry which assures the energy supply and becomes indispensable for the total development of a country. Coal mining started in the Raniganj Coalfield (RCF) area in 1774 during British East India period. The Raniganj Coalfield covers an area of 1530 sq.km, containing about 1306 sq. $\mathrm{km}$ of coal bearing land. There are about 117 coal mines and about 60 sq. $\mathrm{km}$ of the coalfield have been damaged by mining operations. The total estimated coal production is $950 \mathrm{Mt}$. Of these mines, twelve are opencast and 105 underground. In 1987-88 these mine produced $12.17 \mathrm{Mt}$ and $15.84 \mathrm{Mt}$ of coal respectively. Some $61.66 \mathrm{Mt} / \mathrm{y}$ of coal was produced by 2000 , by which time 14000 ha of land in the RCF had been damaged. Mining activities always lead to environmental degradation and pollution. Restoration is the process by which the impacts of mining on the environment are repaired. It is an essential part of developing mineral resources in accordance with the principles of sustainable development. Increasingly, today, the environmental protection sought by mining operators includes the maintenance of biodiversity. Present work has been designed to study the diversity of different groups of microorganisms in relation to the physicochemical properties in the soilhabitats of some coal areas of Raniganj, West Bengal.

\section{Materials and Methods}

The soil samples were collected from seven representative sites of Parascul, Sankerpur Kenda, Nagrakunda, Bankola, Sidhuli, Topsi Colliery, and Sonepur Bazari at Raniganj Coal Field. Top soil was removed and about $500 \mathrm{gm}$ soil samples were collected from seven areas and mixed them thoroughly put in a clean sterile polythene bags, sealed with rubber bands and the samples were analyzed in the laboratory. After completion of assessment of the spoil physicochemical properties like $\mathrm{pH}$, organic carbon, nitrogen, potassium, and phosphorus, following standard methods (Hajek et al. 1972, Isaac et al. 1984, Sumner et al. 1996 and APHA, 1998) soil samples were transported to the microbiological laboratory. By using different selective media and serial dilution method microbiological study were performed. Microbial colonies were enumerated as colony forming units (cfu). The heterotrophic, gram positive, gram negative, phosphate solubilizing, nitrate reducing bacteria were enumerated using the protocol of Pelczar et.al. 1957.

\section{Results and Discussion}

Mining of coal causes massive damage of biological community. But a number of colonies have been found that indicates the presence of particular microbial species at those seven different sites of Raniganj Coalfield region. And microorganism in soil are critical for the maintenance of soil function in both natural and managed agricultural soils because of their involvement in such key processes as soil structure formation, decomposition of organic matter, toxin removal, and the cycling of carbon, nitrogen, phosphorus, and sulphur. Seven different sites of Raniganj Coalfield were inventorized and it was found that the color of soil of these sites was varied from brownish to black and soil 
texture was coarse. The $\mathrm{pH}$ of soil was tabulated in Table: 1 which varied from 4.5 to 10. Microbiological studies were performed by using different media which tabulated in Table: 2. Serial dilution of soil were performed and by using selective media different agar plates were prepared for producing colonies in petriplate. These colonies suggest the presence of particular microbial population on those sites of Raniganj Coalfield. Heterotrophic bacterial population ranged from $1.2 \times 10^{4}$ to $8.5 \times 10^{4}$ and Nitrate reducing bacterial populations was varied from $4.0 \times 10^{4}$ to $8.0 \times 10^{4}$ on those different sites of Raniganj Coalfield. Heterotrophic bacterial populations were much higher in Sankerpur kenda area where in Topsi Colliery region these populations were too much lower (Table 2). Nitrate reducing bacterial population was low in Bankola region, but found high in Sidhuli region (Table 2). Gram positive bacterial population ranged from $2.5 \times 10^{4}$ to 7.0 $\mathrm{X} 10^{4}$ and gram negative from $1.0 \times 10^{4}$ to $7.0 \times 10^{4}$ at different sites of Raniganj Coalfield area.

Table.1 Physico-Chemical Characteristics of Soil Samples

\begin{tabular}{|l|l|l|l|l|l|l|l|}
\hline Area & Color & Texture & $\mathrm{pH}$ & $\begin{array}{l}\text { Nitrogen } \\
(\mathrm{Kg} / \text { Acre })\end{array}$ & $\begin{array}{l}\text { Potassium } \\
(\mathrm{Kg} / \text { Acre })\end{array}$ & $\begin{array}{l}\text { Phosphorus } \\
\text { (Kg/Acre) }\end{array}$ & $\begin{array}{l}\text { \% of } \\
\text { Organic } \\
\text { Carbon }\end{array}$ \\
\hline Nagrakunda & Brownish & Coarse & 4.5 & 80 & 40 & 11 & 0.40 \\
\hline Parascul & Brownish & Coarse & 4.5 & 80 & 20 & 8 & 0.45 \\
\hline $\begin{array}{l}\text { Topsi } \\
\text { Colliery }\end{array}$ & Brownish & Coarse & 10.0 & 25 & 20 & 11 & 0.45 \\
\hline $\begin{array}{l}\text { Sonepur } \\
\text { Bazari }\end{array}$ & Brownish & Coarse & 10.0 & 80 & 20 & 18 & 0.76 \\
\hline Bankola & Brownish & Coarse & 5.0 & 300 & 20 & 11 & 0.36 \\
\hline $\begin{array}{l}\text { Sankerpur } \\
\text { kenda }\end{array}$ & Black & Coarse & 8.5 & 25 & 20 & 18 & 0.45 \\
\hline Sidhuli & Black & Coarse & 5.0 & 25 & 20 & 2 & 0.40 \\
\hline
\end{tabular}

Table.2 Microbial Diversity in Different Soil Sample (Cfu/Gm of Soil)

\begin{tabular}{|l|l|l|l|l|l|l|l|}
\hline \multicolumn{1}{|c|}{$\begin{array}{c}\text { Bacterial } \\
\text { Population }\end{array}$} & \multicolumn{6}{|c|}{ Area } \\
\hline & Nagrakunda & Parascul & $\begin{array}{l}\text { Topsi } \\
\text { Colliery }\end{array}$ & $\begin{array}{l}\text { Sonepur } \\
\text { Bazari }\end{array}$ & Bankola & $\begin{array}{l}\text { Sankerpur } \\
\text { Kenda }\end{array}$ & Sidhuli \\
\hline Heterotrophic $\left(\mathrm{x} 10^{44}\right)$ & 3.5 & 5.0 & 1.2 & 7.5 & 2.0 & 8.5 & 6.5 \\
\hline Gram positive $\left(\mathrm{x} 10^{4}\right)$ & 4.5 & 3.0 & 7.0 & 3.6 & 5.0 & 2.5 & 3.1 \\
\hline Gram negative $\left(\mathrm{x} 10^{4}\right)$ & 7.0 & 4.0 & 1.5 & 4.8 & 1.0 & 7.0 & 5.0 \\
\hline Nitrate reducing (x10 $)$ & 6.8 & 7.0 & 6.5 & 7.8 & 4.0 & 6.0 & 8.0 \\
\hline $\begin{array}{l}\text { Phosphate solubilising } \\
\left(\mathrm{x} 10^{4}\right)\end{array}$ & 2.0 & 3.7 & 4.0 & 3.0 & 1.1 & 7.8 & 2.0 \\
\hline
\end{tabular}

$\mathrm{Cfu}=$ colony forming unit

Gram negative bacterial populations were low in Bankola region, but found high in
Sankerpur kenda and Nagrakunda region (Table 2). Maximum gram positive were 
found in Topsi Colliery area. Phosphate solubilizing bacterial pollution ranged from $1.1 \times 10^{4}$ to $7.8 \times 10^{4}$ at seven different sites of Raniganj Coalfield, that bacterial population was too much low in Bankola region where it was found high in Sankerpur Kenda area. Nitrogen quantity was too much lower at Topsi colliery area where as phosphorus quantity was much lower at Sidhuli area. Potassium quantity was averagely same and low in different areas of RCF except Nagrakunda. Organic carbon content was too much high in Sonepur Bazari area whereas other area was averagely low in according to organic carbon quantity. So it was found at Sonepur Bazari, higher quantity of organic matter present which was important for soil fertility and other regions were required to raise the level of organic carbon.

\section{References}

APHA, (1998). Standard methods for the examination of Water and Waste Water, $20^{\text {th }}$ Edition. American Public Health Association, Washington DC.

Atlas, R.M., Horowitz, A., Krichevsky, M. and Bej, A.K., (1991). Responses of microbial populations to environmental disturbance. Microb Ecol. 22:249-256..

Chatterjee, S. N., Chattoraj, K., Banerjee, P., De, M.K., and Majumdar, A., (2012). Population dynamics and diversity of soil microbes in some areas of Jalpaiguri district of West Bengal, India. Asian Journal of Microbiol. Biotech. Env. Sc. Vol. 15, No. (2): 2013: 287-290.

Chatterjee, S.N., Das, D., and Dangar, T.K., (2008). Efficacy of Bacillus sphaericus against Aedes (Stegomyia) aegypti, Mansonia Indiana (Edward) and Culex vishnui. Entomon. 33(3): 181-187.
Chatterjee, S.N., and Ghosh, T.S., (2010). Characterization of ampicillin resistant Bacillus sp isolated from the midgut of Anopheles barbirostris (Van der Wulp) and its role on larval development. J. Pure and Applied Microbiology. 4(2): 875-878.

Chatterjee, S.N., Ghosh, T.S., and Das, S., (2010). Virulence of Bacillus cereus as natural facultative pathogen of Anopheles subpictus Grassi (Diptera: Culicidae) larvae in submerged rice-fields and shallow ponds. African J. Biotechnology. 9(41): 6983-6987.

Chatterjee, S.N., Rudra, S.K., Ghosh, T.S., and Dhal, P.K., (2011). Molecular characterization and phylogenetic analysis of mosquito pathogenic Bacillus cereus (HM026606). Proceedings of $22^{\text {nd }}$ National Congress of Parasitology, University of Kalyani, West Bengal (ISBN: 978-95-3-5067-220-4): 293-298.

Das, J., Danger, T.K., (2008). Microbial population dynamic, especially Bacillus thuringiensis, in partially aerobic rice field soils during postharvest period of the Himalayan, island, brakish water and coastal habitats of India. World J. Microbiol. Biotechnol. 24, 14031410.

Hajek, B.F., Adams, F. And Cope, J.T., (1972). Rapid determination of exchangeable bases, acidity, and base saturation for soil characterization. 36: 436-438.

Isaac, Robert, A. and William, C. Johnson, (1984). (revised). University of Georgia, Athens, Ga.

Pelczar, Jr. M.J., Bard, R.C., Burnett, G.W., Conn, H.J., Demoss, R.D., Euans, E.E., Weiss, F.A., Jennison, M.W., Meckee, A.P., Riker, A.J., Warren, J., Weeks, O.B., (1957). Manual of 
Microbiological Methods. McGraw Hill Book Company, Inc., New York. Soc. Am. Bacteriol.

Raich, J.W. and Potter, C.S. (1995). Global patterns of carbon dioxide emissions from soils. Global Biogeochem. Cycles. 9: 23-36.

Kaneko, T., Atlas, R.M., Krichevsky, M., (1977). Diversity of bacterial populations in the Beaufort Sea. Nature. 270: 596-599.

Schimel, D.S., (1995). Terrestrial ecosystems and the carbon cycle. Global change Biol. 1: 77-91.

Schlesinger, W.H., (1997). Biogeochemistry: An Analysis of Global Change. Academic Press,
San Diego, CA.

Sumner, M.E. and Miller, W.P. (1996). Cation Exchange Capacity and Exchange Coefficients. p. 12211222. In: D.L. Sparks (ed). Soil Science Society of America Book Ser. 5. SSSA and ASA, Madison, Wis.

Vitousek, P.M., Aber,J. D., Howarth, R. W., Likens, G. E., Matson, P. A., Schindler, D. W., Schlesinger, D. H. and Tilman, D. (1997). Human alteration of the global nitrogen cycle: sources and consequences. Ecol. Appl. 7: 737-750.

\section{How to cite this article:}

Payel Majumder and Debnath Palit. 2016. Microbial Diversity of Soil in Some Coal Mine Generated Wasteland of Raniganj Coalfield, West Bengal, India. Int.J.Curr.Microbiol.App.Sci.5(2): 637-641. doi: http://dx.doi.org/10.20546/ijcmas.2016.502.071 